\title{
Hubungan tingkat kepercayaan diri dengan jerawat (acne vulgaris) pada remaja di SMAN 7 Manado
}

\author{
${ }^{1}$ Elga Elfina Ompi \\ ${ }^{2}$ Lydia David \\ ${ }^{2}$ H. Opod
}

\author{
1Kandidat Skripsi Fakultas Kedokteran Universitas Sam Ratulangi Manado \\ 2Bagian Psikologi Fakultas Kedokteran Universitas Sam Ratulangi Manado \\ Email: elgaompi@yahoo.com
}

\begin{abstract}
Abstrak. Remaja dengan penampilan fisik berjerawat yang tidak sesuai dengan gambaran idealnya, dikatakan memiliki kepercayaan diri tinggi apabila ia mampu menerima dengan realistis dan mensyukuri serta bertindak positif sedangkan kepercayaan diri rendah apabila remaja tersebut merasa tidak puas, malu, kecewa dan menolak keadaan dirinya. Jerawat atau acne vulgaris adalah peradangan folikel sebasea yang ditandai oleh komedo, papula, pustula, kista dan nodulus di wajah, leher, badan atas dan lengan atas. Jerawat cukup merisaukan karena berhubungan dengan menurunnya kepercayaan diri akibat berkurangnya keindahan wajah penderita. Penelitian ini bertujuan untuk menganalisis hubungan tingkat kepercayaan diri dengan jerawat. Jenis penelitian ini adalah korelasional dengan pendekatan waktu cross sectional (potong lintang). Subyek penelitian adalah siswa/i kelas X-XII SMA Negeri 7 Manado yang berjerawat dengan jumlah 90 responden yang dipilih dengan cara purposive sampling. Untuk menganalisis hubungan antara tingkat kepercayaan diri dengan jerawat digunakan teknik analisis Rank Spearman. Hasil penelitian menunjukkan bahwa nilai koefisien korelasi antara jerawat dengan kepercayaan diri sebesar -0,068, artinya jerawat dengan kepercayaan diri memiliki hubungan negatif dimana keeratan korelasinya sangat lemah $(<0,20)$ sehingga dapat dikatakan tidak terdapat hubungan signifikan antara kepercayaan diri dengan jerawat (Sig=0,523). Artinya, kondisi fisik dalam hal ini jerawat bukan satu-satunya faktor yang mempengaruhi kepercayaan diri. Konsep diri, pengalaman, pendidikan merupakan faktor internal dan orang tua, teman sebaya dan masyarakat merupakan faktor eksternal yang bisa mempengaruhi kepercayaan diri. Responden yang memiliki kepercayaan diri tinggi walaupun berjerawat tidak berorientasi pada penampilan fisik semata, karena mereka merasa yakin akan kemampuan dan potensi dirinya pada hal-hal yang lain.
\end{abstract}

Kata kunci: Remaja, Kepercayaan Diri, Jerawat.

Abstract. Adolescents with acne in physical appearance that doesn't like the ideal appearance, is said that have confidence when he can accept realistically, still feel grateful and act positively while low confidence if these adolescents are not satisfied, embarrassed, disappointed, and rejected themselves. Acne vulgaris is the inflammation of the sebaceous follicles characterized by comedones, papules, pustules, cysts and nodules on the face, neck, upper trunk and upper arms. Acne is troubling because it is related to the degradation of self confidence due to the beauty of the face.This study aimed to analyze the relationship between the level of confidence with acne. This type of study is correlational with cross sectional approach. The subjects are SMAN 7 Manado students who have acnes with 90 respondents chosen by purposive sampling. Spearman Rank analysis techniques is used to.The results showed that the correlation coefficient between acne with confidence at -0.068 , meaning the relationship between acne and confidence is negative which the closeness of the correlation is very weak $(<0.20)$ so that it can 
be said there is no significant relationship between confidence with acne ( $\operatorname{Sig}=0.523$ ). It means, the physical appearance in this case the acne is not the only factor affecting confidence. Self-concept, experience, education is the internal factors and their parents, peers and the community are the external factors that can affect confidence. Respondents with high self confidence eventhough have acnes are not oriented on their physical appearance alone, , because they feel confident in the ability and potential for him in other things.

Keywords: Adolescents, Confidence, Acne.

Kepercayaan diri merupakan suatu kemampuan untuk mempercayai kemampuan sendiri dan merasa positif tentang apa yang bisa dilakukan dan tidak mengkhawatirkan apa yang tidak bisa dilakukan. ${ }^{1}$ Rasa percaya diri penting dimiliki oleh setiap orang karena rasa percaya diri mendorong seseorang untuk menghadapi situasi dengan pikiran jernih dan menerima kelemahan diri sehingga tidak terpuruk pada perasaan bersalah dan rendah diri yang dapat menghambat dalam mengoptimalkan potensi yang dimiliki. ${ }^{2}$ Terkait dengan kepercayaan diri ini, Koentjaraningrat menyatakan bahwa salah satu kelemahan generasi muda atau remaja adalah kurangnya kepercayaan diri. ${ }^{3}$

Remaja dalam perkembangannya, dihadapkan oleh berbagai perubahan, mencakup perubahan biologis dan psikologis. Perubahan biologis yang terdiri dari perubahan fisik merupakan pencetus yang berdampak pada tahap psikis. ${ }^{4}$ Perubahan kondisi fisik inilah yang berpengaruh pada kepercayaan diri. Penampilan fisik seperti wajah berjerawat yang tidak sesuai dengan gambaran ideal seorang remaja akan menimbulkan ketidakpuasan sehingga menimbulkan rasa kurang percaya diri. ${ }^{5}$ Hal ini sejalan dengan pendapat Anthony yang mengatakan bahwa penampilan fisik merupakan penyebab utama rendahnya harga diri dan percaya diri seseorang. ${ }^{6}$ Jerawat atau dalam bahasa medisnya acne vulgaris adalah peradangan folikel sebasea yang ditandai oleh komedo, papula, pustula, kista dan nodulus ditempat predileksinya yaitu di wajah, leher, badan atas dan lengan atas. ${ }^{7}$ Berdasarkan penelitian Goodman, prevalensi tertinggi yaitu pada umur 16-17 tahun. ${ }^{7}$ Pada waktu pubertas terjadi peningkatan hormon androgen yang beredar dalam darah yang menyebabkan hiperplasia dan hipertrofi glandula sebasea, sehingga tidak heran angka kejadian jerawat paling tinggi pada usia remaja. ${ }^{7}$ Walaupun tidak mengancam kehidupan, jerawat cukup merisaukan karena berhubungan dengan menurunnya kepercayaan diri akibat berkurangnya keindahan wajah penderita.Pada penelitian Ritvo Eva at $a l^{8}$ dari 1002 responden, remaja yang berjerawat dilaporkan memiliki kepercayaan diri rendah atau rasa malu (71\%), kesulitan menemukan pasangan (43\%), masalah dalam interaksi dengan teman (24\%), masalah berkaitan dengan kegiatan di sekolah (21\%), dan kesulitan mendapatkan pekerjaan (7\%). Penelitian dari Tasoula E at al $^{9}$ pada 1531 remaja berjerawat, menunjukkan bahwa acne vulgaris mempengaruhi kehidupan seharihari. Remaja dengan acne vulgaris 46,8\% menunjukkan rasa malu dan harga diri rendah, 21,4\% mempengaruhi aktivitas di sekolah, 19,4\% mempengaruhi hobi, 19,2\% mempengaruhi kehidupan sosial, 14\% menghindar dari kegiatan fisik karena malu dengan wajah berjerawat. $^{9}$ Beberapa penelitian diatas menunjukkan walaupun jerawat tidak berbahaya, namun jerawat dapat menyebabkan konsekuensi psikologis yang serius dan menimbulkan efek negatif pada kualitas hidup penderita. ${ }^{10}$ Hal ini membuat peneliti tertarik untuk melakukan penelitian mengenai hubungan tingkat kepercayaan diri dengan jerawat pada remaja di SMAN 7 Manado. 


\section{METODE PENELITIAN}

Jenis penelitian ini adalah korelasional dengan pendekatan waktu cross sectional (potong lintang). Waktu penelitian bulan Desember 2015. Objek penelitian adalah siswa/i kelas X-XII SMA Negeri 7 Manado yang berjerawat dengan jumlah 90 responden yang dipilih dengan cara purposive sampling. Dalam penelitian ini terdapat 1 variabel bebas yaitu "Jerawat", dan 1variabel terikat yaitu "Kepercayaan Diri”. Untuk pengumpulan data digunakan kuisioner/angket berdasarkan penelitian Indra Beni Rupang dengan 48 pernyataan kemudian dimodifikasi sesuai dengan keperluan penelitian menjadi 32 pernyataan. Setelah dilakukan uji validitas dan reliabilitas (yang penghitungannya menggunakan program SPSS versi 20.0) kepada 30 remaja berjerawat di SMAN 7 Manado, didapatkan 28 pernyataan valid dan empat pernyataan tidak valid dan diperoleh nilai Alpha Cronbach sebesar 0,688 (> 0,60 ) yang menyatakan bahwa instrumen reliabel.

Untuk menganalisis hubungan antara tingkat kepercayaan diri dengan jerawat digunakan teknik analisis Rank Spearman dengan menggunakan program SPSS (Statistical Package for Social Science) versi 20.0.

HASIL

Tabel 1 Deskripsi Responden berdasarkan Gradasi Jerawat

\begin{tabular}{|c|c|c|c|}
\hline Keterangan & Bobot & Jumlah & Persentase \\
\hline Ringan & 1 & $\begin{array}{l}45 \\
\text { Orang }\end{array}$ & $50 \%$ \\
\hline Sedang & 2 & $\begin{array}{l}38 \\
\text { Orang }\end{array}$ & $42.2 \%$ \\
\hline Berat & 3 & $\begin{array}{l}7 \\
\text { Orang }\end{array}$ & $7.8 \%$ \\
\hline Total & & $\begin{array}{l}90 \\
\text { Orang }\end{array}$ & $100 \%$ \\
\hline
\end{tabular}

Tabel 1 menunjukkan responden terbanyak memiliki gradasi jerawat ringan yaitu 45 responden (50\%).
Tabel 2 Deskripsi Responden berdasarkan Tingkat Kepercayaan Diri

\begin{tabular}{|c|c|c|c|}
\hline Keterangan & Range & $\begin{array}{l}\text { Jumla } \\
\text { h }\end{array}$ & $\begin{array}{l}\text { Persen } \\
\text { tase }\end{array}$ \\
\hline Sangat Rendah & $28-44,8$ & - & - \\
\hline Rendah & $44,8-61,6$ & - & - \\
\hline Sedang & $61,6-78,4$ & $\begin{array}{l}3 \\
\text { Orang }\end{array}$ & $3,33 \%$ \\
\hline Tinggi & $78,4-95,2$ & $\begin{array}{l}52 \\
\text { Orang }\end{array}$ & $\begin{array}{l}57,78 \\
\%\end{array}$ \\
\hline Sangat Tinggi & $95,2-112$ & $\begin{array}{l}35 \\
\text { Orang }\end{array}$ & $\begin{array}{l}38,89 \\
\%\end{array}$ \\
\hline Total & & $\begin{array}{l}90 \\
\text { Orang }\end{array}$ & $100 \%$ \\
\hline
\end{tabular}

Pada tabel 2 menunjukkan responden terbanyak memiliki tingkat kepercayaan diri tinggi 52 orang dengan range 78,4-95,2 $(57,78 \%)$.

Tabel 3 Deskripsi Responden berdasarkan Gradasi Jerawat dan Tingkat Kepercayaan Diri.

\begin{tabular}{lllll}
\hline Kepercayaan & \multicolumn{3}{c}{ Gradasi Jerawat } & Total \\
\cline { 2 - 4 } Diri & Berat & Sedang & Ringan & \\
\hline Sangat & - & - & - & - \\
Rendah & & & - & - \\
Rendah & - & - & - & - \\
Sedang & 1 & 2 & - & 3 \\
& Orang & Orang & & Orang \\
Tinggi & 4 & 18 & 30 & 52 \\
& Orang & Orang & Orang & Orang \\
SangatTinggi & 2 & 15 & 18 & 35 \\
& Orang & Orang & Orang & Orang \\
\multirow{2}{*}{ Total } & 7 & 35 & 48 & 90 \\
& Orang & Orang & Orang & Orang \\
\hline
\end{tabular}

Tabel 3 menunjukkan bahwa responden terbanyak adalah yang memiliki gradasi jerawat ringan dengan kepercayaan diri tinggi (30 responden).

Tabel 4 menunjukkan pada variabel kepercayaan diri, nilai rata-ratanya adalah sebesar 93,1778, nilai median sebesar 93, standar penyimpangan sebesar 9,67747, nilai minimum sebesar 66 dan nilai maksimum sebesar 112. Pada variabel gradasi jerawat nilai rata-ratanya adalah sebesar 1,5778, nilai media sebesar 1,5, 
standar penyimpangan sebesar 0,63561, nilai minimum sebesar 1 dan nilai maksimum sebesar 3 .

Tabel 4 Analisa Deskriptif

\begin{tabular}{lll}
\hline & $\begin{array}{l}\text { Kepercayaan } \\
\text { Diri }\end{array}$ & $\begin{array}{l}\text { Gradasi } \\
\text { Jerawat }\end{array}$ \\
\hline $\mathrm{N}$ & Valid & 90 \\
& Missing & 0 \\
Mean & 93.1778 & 1.5778 \\
Median & 93.0000 & 1.5000 \\
Std. & 9.67747 & .63561 \\
Deviation & &
\end{tabular}

\begin{tabular}{lll} 
Minimum & 66.00 & 1.00 \\
Maximum & 112.00 & 3.00 \\
\hline
\end{tabular}

Pada tabel 5 didapatkan nilai signifikansi $0,523(>0,05)$ dan nilai koefisien korelasi sebesar -0,068 yang menujukkan gradasi jerawat dengan kepercayaan diri memiliki hubungan negatif dimana keeratan korelasinya sangat lemah $(<0,20)$ sehingga dapat dikatakan tidak terdapat hubungan signifikan antara kepercayaan diri dengan gradasi jerawat.

Tabel 5 Analisa Hubungan Antara Gradasi Jerawat dengan Kepercayaan Diri

\begin{tabular}{|c|c|c|c|c|}
\hline & & & Kepercayaan & Gradasi \\
\hline & & & Diri & Jerawat \\
\hline Spearman's rho & Kepercayaan & Correlation & 1.000 & -0.068 \\
\hline & Diri & Coefficient & & \\
\hline & & Sig. (2-tailed) & . & 0.523 \\
\hline & & $\mathrm{N}$ & 90 & 90 \\
\hline & Gradasi Jerawat & Correlation & -0.068 & 1.000 \\
\hline & & Coefficient & & \\
\hline & & Sig. (2-tailed) & 0.523 & $\cdot$ \\
\hline & & $\mathrm{N}$ & 90 & 90 \\
\hline
\end{tabular}

\section{BAHASAN}

Tabel 1 menunjukkan responden yang memiliki gradasi jerawat ringan sebanyak 45 responden dengan persentase $50 \%$ lebih banyak daripada responden yang memiliki gradasi jerawat sedang (42,2\%) maupun berat (7.8\%). hasil penelitian ini sejalan dengan penelitan yang dilakukan Vilar GN at $a l^{11}$ semakin meningkat keparahan jerawat, semakin menurun jumlah penderita jerawat. Artinya gradasi jerawat pada remaja berjerawat paling dominan adalah tingkat gradasi sedang. ${ }^{12,13}$

Pada tabel 2 menunjukkan bahwa tidak ada responden yang berada pada tingkat kepercayaan diri sangat rendah dan rendah. Responden dengan tingkat kepercayaan diri tinggi (57,78\%) lebih banyak daripada responden yang memiliki tingkat kepercayaan diri sedang (3,33\%) dan sangat tinggi (38,89\%). Remaja yang memiliki kepercayaan diri tinggi merasa puas dengan keadaan dan penampilan fisiknya, sehingga remaja tidak akan malu dengan tubuh yang dia miliki bahkan dia dapat mensyukuri keadaan dirinya serta akan mudah bergaul dengan keadaan disekelilingnya.
Menurut Al-Uqshari self confidence adalah keyakinan seorang individu akan kemampuan yang dimiliki sehingga merasa puas dengan keadaan dirinya. ${ }^{14}$

Tabel 3 menunjukkan bahwa responden terbanyak adalah yang memiliki gradasi jerawat ringan dengan kepercayaan diri tinggi (30 responden). Sebenarnya jerawat bukanlah masalah, yang menjadi masalah adalah cara pandang kita. Jika seseorang memiliki cara pandang yang baik terhadap tubuhnya maka dia akan memiliki kepercayaan diri yang tinggi. ${ }^{15}$

Pada umumnya, remaja yang berjerawat akan mengalami perubahan keadaan psikologi berupa rendahnya kepercayaan diri. ${ }^{16}$ Namun pada kenyataanya belum tentu remaja yang berjerawat mengalami kepercayaan diri rendah. ${ }^{16}$ Seperti hasil dalam penelitian ini, remaja yang berjerawat tetap merasa percaya diri, tidak terpengaruh oleh kekurangan pada keadaan fisiknya, seperti jerawat. Suatu saat mereka pasti pernah merasa malu dengan jerawat tersebut, akan tetapi mereka mempunyai mekanisme dan sumber koping yang baik, sehingga jerawat dianggap suatu hal yang tidak 
berarti. Tidak setiap orang memandang kecantikan hanya dari ada dan tidaknya jerawat diwajah mereka. ${ }^{17}$

Pada tabel 5 didapatkan nilai signifikansi 0,523 $(>0,05)$ yang menunjukkan bahwa Ho diterima yang berarti tidak terdapat hubungan yang signifikan antara kepercayaan diri dengan gradasi jerawat. Penelitian ini juga menunjukkan nilai koefisien korelasi antara jerawat dengan kepercayaan diri sebesar 0,068, artinya jerawat dengan kepercayaan diri memiliki hubungan negatif dimana keeratan korelasinya sangat lemah $(<0,20)$ sehingga dapat dikatakan tidak terdapat hubungan signifikan antara kepercayaan diri dengan jerawat. Hal ini menyatakan bahwa kondisi fisik dalam hal ini jerawat bukan satusatunya faktor yang mempengaruhi pembentukan dan perkembangan kepercayaan diri. Ada beberapa faktor yang dapat mempengaruhi kepercayaan diri, dapat berasal dari dalam dan dari luar individu itu sendiri. Faktor yang berasal dari dalam meliputi konsep diri, kondisi fisik, pengalaman, pendidikan dan faktor luar yaitu orang tua, teman sebaya dan sekolah. ${ }^{18}$

Hasil dalam penelitian ini juga dapat ditunjukkan melalui hasil wawancara dengan beberapa responden mengenai kepercayaan diri yang tinggi walapun berjerawat. Pada wawancara singkat tersebut, responden mengatakan bahwa ia percaya diri karena mendapat penerimaan sosial yang baik. Menurut Sullivan jika individu diterima dan disenangi orang lain karena keadaannya, maka individu akan bersikap menghormati dan menerima diri sendiri. ${ }^{19}$ Dukungan emosional dan persetujuan sosial dari orang lain merupakan pengaruh yang penting bagi rasa percaya diri remaja. ${ }^{17}$ Ada juga responden yang mengatakan bahwa ia tetap percaya diri walaupun berjerawat karena banyak terlibat bahkan berprestasi dalam kegiatan ekstrakurikuler di sekolah yaitu sepak bola sehingga ia menganggap jerawat merupakan suatu hal yang tidak berarti dan bukan penghalang dalam berkarya. Hal ini sejalan dengan teori Hakim yang mengatakan bahwa rasa percaya diri siswa di sekolah bisa dibangun melalui berbagai macam bentuk kegiatan salah satunya aktif dalam kegiatan pertandingan olah raga. Hal yang berkaitan diungkapkan oleh Bednar, Wells, \& Peterson bahwa prestasi merupakan salah satu faktor untuk dapat memperbaiki tingkat percaya diri remaja. ${ }^{17}$
Responden lainnya menganggap bahwa munculnya jerawat adalah hal yang wajar di kalangan remaja. Menurutnya secara alamiah jerawat terjadi pada semua orang, sehingga jerawat bukanlah suatu gangguan atau hal yang memalukan. Salah satu responden juga mengatakan bahwa perawatan wajah berjerawat membutuhkan biaya yang bukan sedikit, jadi ia memutuskan untuk menerima dan mensyukuri keadaan wajah berjerawat.

Hal-hal tersebut menyatakan bahwa pandangan yang realistik terhadap diri, menerima dan mensyukuri keadaan wajah berjerawat akan memberi rasa aman, sehingga terhindar dari rasa cemas dan rendah diri. ${ }^{20}$ Individu yang stabil realistis dan konsisten terhadap gambaran dirinya akan memperlihatkan kemampuan mantap terhadap realisasi yang akan memacu sukses di dalam kehidupan. Hasil penelitian ini didukung oleh teori yang menyatakan bahwa remaja yang memiliki kepercayaan diri yang tinggi tidak akan terlalu berorientasi pada penampilan fisik semata, karena mereka merasa yakin akan kemampuan dan potensi dirinya pada hal-hal yang lain. ${ }^{15}$

Setelah melakukan penelitian ini, ada beberapa kelemahan yang ditemukan yaitu kurangnya jumlah sampel dengan gradasi jerawat berat, waktu penelitian yang singkat dan kurang melakukan pendekatan dengan remaja yang berjerawat di SMAN 7.

\section{SIMPULAN}

Hasil penelitian menunjukkan bahwa nilai koefisien korelasi antara jerawat dengan kepercayaan diri sebesar -0,068, artinya jerawat dengan kepercayaan diri memiliki hubungan negatif dimana keeratan korelasinya sangat lemah $(<0,20)$ sehingga dapat dikatakan tidak terdapat hubungan signifikan antara kepercayaan diri dengan jerawat (Sig=0,523).

\section{SARAN}

Bagi peneliti selanjutnya mempertimbangkan variabel-variabel lain yang berhubungan dengan kepercayaan diri pada remaja, seperti konsep diri, pengalaman hidup, pendidikan, ekonomi, pola asuh orang tua, teman sebaya dan sekolah serta meneliti pada subjek yang lain, seperti siswa/i Sekolah Menengah Pertama 
(SMP), mahasiswa dan orang yang sudah bekerja.

\section{UCAPAN TERIMA KASIH}

Ucapan terima kasih disampaikan kepada Dr. dr. Theresia Kaunang, SpKJ dan Cicilia Pali, M.Psi serta pada semua pihak yang baik secara langsung maupun tidak langsung telah menumbuhkan ide atau gagasan dalam pemikiran penulis sehingga dapat menyelesaikan artikel ini.

\section{DAFTAR PUSTAKA}

1. Rombe Sufrihana. Hubungan Body Image dan Kepercayaan Diri dengan Perilaku Konsumtif pada Remaja Putri di SMA Negeri 5 Samarinda. eJournal Psikologi. 2014;2:76-91.

2. Farida NI. Upaya Meningkatkan Kepercayaan Diri Siswa Remaja Putri yang Mengalami Pubertas Awal melalui Layanan Penguasaan Konten dengan Teknik Role Playing di Kelas VII SMPN 13 Semarang Tahun Ajaran 2013/2014. [diakses 3 Okt 2015] dari : http://lib.unnes.ac.id/20066/1/13014 09034.pdf

3. Putri ELM, Darmawanti Ira. Perbedaan Kepercayaan Diri Remaja Akhir Ditinjau Dari Persepsi Terhadap Pola Asuh Orang Tua. Character. 2015;3(2):1-6.

4. Kluytmans Frits. Perilaku Manusia (Pengantar Singkat tentang Psikologi). Bandung:PT Refika Aditama; 2006. h. 44.

5. Marita GAD, Yuliadi S, Karyanta NA. Hubungan antara Body Image dan Imaginary Audience dengan Kepercayaan Diri pada Siswi Kelas $X$ SMA Negeri 2 Nganjuk. Jurnal Ilmiah Psikologi CandraJiwa. 2014;3:145-155.

6. Rupang I, Opod H, Sinolungan J. Hubungan Tingkat Kepercayaan Diri dengan Obesitas pada Siswa SMA Rex Mundi Manado. e-Biomedik (eBM). 2013;1:343-8.

7. Andy. Pengetahuan dan Sikap
Remaja SMA Santo Thomas 1 Medan terhadap Jerawat. [diakses 3 okt 2015]. dari : http://repository.usu.ac.id/bitstream/ 123456789/14281/1/09E02906.pdf

8. Ritvo E, Rosso JQD, Stillman MA, Riche CL. Psychosocial Judgements and Perceptions of Adolescents with Acne Vulgaris: A Blinded, Controlled Comparison of Adult and Peer Evaluations. Biopsychosoc Med. 2011;5:11

9. Tasoula E, Gregoriou S, Lazarou D, Chalikias J, Danopoulou I, Katsambas A at al. The Impact of Acne Vulgaris on Quality Of Life and Psychic Health In Young Adoloscents in Greece. Result of A Population Survey. An Bras Dermatol. 2012;87(6):862-9

10. Gurriannisha Ririn. Gambaran Tingkat Pengetahuan dan Sikap Siswa SMA Negeri 5 Medan terhadap Jerawat Tahun 2010. [diakses 4 okt 2015] dari:http://repository.usu.ac.id/bitstre am/123456789/25848/5/Chapter\%20 I.pdf

11. Vilar GN, Filho JFS, Santos LA. Quality of Life, Self Esteem and Psychosocial Factors in Adoloscents with Acne Vulgaris. An Bras Dermatol. 2015;90(5):622-9.

12. Ribas J, Oliveira CMPB. Acne Vulgaris and Well-Being in Medical Students. An Bras Dermatol. 2008;83:520-5.

13. Costa A, Alchorne MMA, Goldschmidt MCB. Etiopathogenic Feature of Acne Vulgaris. An Bras Dermatol. 2008;83:451-9.

14. Sembiring AS. Kepercayaan diri pada Atlet Basket di Universitas Sumatera Utara Tahun 2014. [diakses 15 Januari 2016]. dari : http://repository.usu.ac.id/bitstream/ 123456789/42528/4/Chapter\%20II.p df

15. Ambarmini Defi. Hubungan Body Image Perubahan Fisik pada Masa 
Remaja dengan Kepercayaan Diri pada Remaja Kelas XI di SMA Negeri 1 Toroh Kabupaten Grobogan[skripsi].2014.

16. Ridwan A, Astutik WS, Astutik YD. Hubungan Tingkat Pengetahuan Dengan Konsep Diri Remaja Putri Yang Mengalami Jerawat (Akne Vulgaris). JurnalAKP. 2010;1:19-21.

17. Siahaan SR. Pengaruh Kepercayaan Diri Remaja Terhadap Pengambilan Keputusan dalam Memilih Jurusan di Perguruan Tinggi. [diakses 15 Januari 2016]. dari : https://www.academia.edu/7823976/ BAB_2_LANDASAN_TEORI_2.1

18. Pratama Rian Ardi. Peningkatan Kepercayaan Diri Melalui Pelatihan Asertif pada Siswa Kelas VIII C
SMPN 2 Bukateja Tahun Pelajaran 2013/2014. [diakses 10 okt 2015]. dari

http://journal.student.uny.ac.id/jurnal /artikel/10307/90/1082

19. Widyaningtyas Diva, Farid M. Pengaruh Experiential Learning terhadap Kepercayaan Diri dan Kerjasama Tim Remaja. Persona, Jurnal Psikologi Indonesia. 2014;3:237-246.

20. Hermawan DG. Gambaran Konsep Diri Remaja Putri yang Menderita Acne Vulgaris di SMK Negeri 1 Indramayu Tahun 2012. [diakses 15 Januari 2016]. dari : https://www.scribd.com/doc/166987 101/Skripsi-Deni-Giri-HermawanBab-I-bab-Vii. 